Biol. Stud. 2020: 14(3); 105-110 • DOI: https://doi.org/10.30970/sbi.1403.631

www.http://publications.Inu.edu.ua/journals/index.php/biology

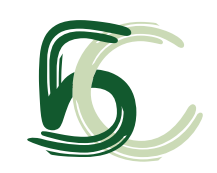

UDC: [598.161:591.477](438-15)

\title{
INTRASPECIFIC VARIABILITY OF THE QUANTITY OF POSTNASAL AND LOREAL SCALES OF THE SAND LIZARD (LACERTA AGILIS) FROM THE WESTERN POLAND
}

\author{
M. Wieczorek ${ }^{\circledR *}$, B. Najbar \\ University of Zielona Góra, Faculty of Biological Sciences \\ 1, Prof. Z. Szafrana St., 65-516 Zielona Góra, Poland \\ *Corresponding author e-mail: M.Wieczorek@wnb.uz.zgora.pl
}

Wieczorek M., Najbar B. Intraspecific variability of the quantity of postnasal and loreal scales of the sand lizard (Lacerta agilis) from the western Poland. Studia Biologica, 2020: 14(3); 105-110 • DOI: https://doi.org/10.30970/sbi.1403.631

Background. The sand lizard Lacerta agilis (Linnaeus, 1758) is widespread throughout Eurasia. So far, several of its subspecies have been described, but only ten of them have been officially recognized. There are two subspecies in Poland: L. agilis agilis and $L$. agilis argus, but their exact range has not been determined yet. One of the main features that is officially considered an acceptable taxonomic index is the triangular arrangement (1/2) of two postnasal scales (scuta postnasalia) and one loreal scale (scuta frenale). However, in many L. agilis populations, significant deviations from the typical pattern of these scales were found.

Methods. 607 sand lizards were caught. 170 in Żary, 150 in Zielona Góra, and 287 in Nowa Sól. The lizards were caught by hand. Their age, sex (adult female, adult male, or juvenile specimens) and the number of sc. postnasalia and sc. frenale were determined. Detailed photographic documentation of each individual was also made.

Results. A typical arrangement of postnasal scales and a loreal scale was observed in $83 \%$ of the lizards from Żary, $78.6 \%$ lizards from Zielona Góra and $77 \%$ lizards from Nowa Sól. The most common deviations from the pattern $1 / 2$ occurred in the lizards from Nowa Sól. Their biggest variations related to as many as 9 deviations (1/0, 1/1, 1/3, 2/0, $2 / 1,2 / 2,2 / 3,2 / 7$ and 3/2). $25 \%$ of changes in the arrangement of the scales were detected in males, $27 \%$ of changes were observed in females, and $16 \%$ in juveniles. The 2/2 arrangement was the most common. The lizards from Zielona Góra had the smallest variation of deviations as they occurred only in two patterns, namely $1 / 1,1 / 2$ with equal frequency. The scale arrangements that have been described occurred in $25 \%$ of males,

(C) 2020 M. Wieczorek et al.; Published by the Ivan Franko National University of Lviv on behalf of Біологічні Студії / Studia Biologica. This is an Open Access article distributed under the terms of the Creative Commons Attribution License (http://www.budapestopenaccessinitiative.org and Creative Commons Attribution 4.0 License), which permits unrestricted reuse, distribution, and reproduction in any medium, provided the original work is properly cited.

ISSN 1996-4536 (print) • ISSN 2311-0783 (on-line) • Біологічні Студії / Studia Biologica • 2020 • Том 14/№3 • C. 105-110 
$27 \%$ of females and $14 \%$ of juveniles. In lizards from Żary, the changes related to four patterns of deviations. Specifically, the $1 / 1,2 / 1,2 / 2$ and $3 / 2$, and $2 / 2$ pattern was the most common. Various scale arrangements were observed within the same population in $20 \%$ of males, $15 \%$ of females and $17 \%$ of juveniles. No differences in the occurrence of deviations among the populations $(x 2=10.83, d f=10, P=0.37)$ and between females and males $\left(x^{2}=9.97, d f=1, P=0.99\right)$ were observed, however, considerable differences between adults and juveniles $\left(x^{2}=4.60, d f=1, P=0.032\right)$ were noticed.

Conclusion. The results confirmed the observations of other scientists who pointed to a considerable variation in the morphology of sc. postnasalia and sc. frenale in the sand lizards. It was stated that the number and the arrangement of the aforementioned scales is not a reliable and consistent feature that can always be applied in order to consistently identify $L$. agilis in western Poland.

Keywords: Lacerta agilis, taxonomy, morphology, differentiation

\section{INTRODUCTION}

The sand lizard Lacerta agilis (Linnaeus, 1758) is widely distributed across Eurasia, though there is uncertainty as to the number of their different geographic subspecies. To date, several subspecies of $L$. agilis have been described $[4 ; 5 ; 9 ; 11 ; 13]$. However, only ten of them have been officially recognised [15]. Morphometric data such as the length of the head, the length of the trunk and the tail, body proportions and colour are the most important distinctive features of the individual subspecies. In this research, however, the analysis of the number and arrangement of the postnasal scales (scuta postnasalia) and the loreal scale (scuta frenale) were taken into consideration in the area under study. For both subspecies L. agilis agilis (Linnaeus, 1758) and L. agilis argus (Laurenti, 1768), one of the most reliable taxonomic identifiiers is the trianglular arrangement (1/2) of the two sc. postnasalia and one sc. frenale. This method of differentiating the lizards is also common in literature which discusses the identification of Polish herpetofauna [3; 8]. However, numerous deviations were noticed in this area within European populations of the species $[5 ; 6 ; 10]$.

The main aim of this research was to determine the frequency of changes in the arrangement and number of sc. postnasalia and sc. frenale in the sand lizards from three populations in western Poland, to compare the frequency of anomalies concerning the features in question depending on their sex and age (including adult females, adult males and juveniles), and to decide whether the arrangement and the number of the scales mentioned above is a reliable taxonomic feature indeed.

\section{MATERIALS AND METHODS}

The research was conducted in three separate study areas in western Poland: Żary, Zielona Góra and Nowa Sól between 28 March 2016 and 3 October 2016 and 12 April 2017 and 19 October 2017. The specific coordinates of each location are: (1) Żary $\left(51^{\circ} 37.690^{\prime} \mathrm{N}, 1^{\circ} 05.387^{\prime} \mathrm{E}\right)$, (2) Zielona Góra $\left(51^{\circ} 52.188^{\prime} \mathrm{N}, 1^{\circ} 27.122^{\prime} \mathrm{E}\right)$ and 3) Nowa Sól $\left(51^{\circ} 43.850^{\prime} \mathrm{N}, 15^{\circ} 43.816^{\prime} \mathrm{E}\right)$.

The area selected in Żary is a gravel pit. Approximately $42 \%$ of the area is covered in trees such as young scots pines (Pinus sylvestris) and common aspen (Populus tremula). The area is covered with grass, the most dominant being bushgrass (Calamagrostis

ISSN 1996-4536 (print) • ISSN 2311-0783 (on-line) • Біологічні Студії / Studia Biologica • 2020 • Том 14/№3 • С. 105-110 
epigejos), which covers $30 \%$ of the land. Wetland constitutes $24 \%$ and small water bodies form $4 \%$ of the area.

In Zielona Góra, a post-agricultural location with a development of small housing estates was selected. $69 \%$ of the selected land is barren or covered in meadows (Arrhenatheretalia elatioris). $23.5 \%$ is covered by riparian forests (Alno-Ulmion) and the remaining $6.3 \%$ of the area is developed. Plants such as colonial bentgrass (Agrostis capillaris), false oat-grass (Arrhenatherum elatius), tall oat grass (Poa pratensis), soft brome (Bromus hordeaceus), bushgrass (Calamagrostis epigejos), hawthorn (Crataegus spp.), rosehip (Rosa canina), black tower (Sambucus nigra) and blackberry (Rubus spp.) prevail in this area.

Nowa Sól is a transformed, post-mining area with a lot of sunlight. $83 \%$ of the land is covered by grassland that grows on high hills and $12 \%$ of the area is covered by bushes and shrubs. Xerophytes such as grey hair-grass (Corynephorus canescens), campion (Silene spp.) and crested hair-grass (Koeleria macrantha) prevail in this area. Small water bodies cover only $5 \%$ of the whole area.

607 sand lizards were caught: 170 in Żary, 150 in Zielona Góra, and 287 in Nowa Sól (see Table). The lizards were caught by hand. Their age, sex (adult female, adult male, or juvenile specimens) and the number of sc. postnasalia and sc. frenale were determined. Detailed photographic documentation of each individual was made, taking into account the number, position and shape of the scales of the head.

\section{RESULTS}

A typical arrangement of postnasal scales and a loreal scale (Table, Fig. 1A) was observed in $83 \%$ of the lizards from Żary, 78.6 \% lizards from Zielona Góra and 77 \% lizards from Nowa Sól.

The number of the sand lizards categorized according to age and sex including typical and non-typical arrangements of scuta postnasalia and scuta frenale

\begin{tabular}{|c|c|c|c|c|c|c|c|c|c|}
\hline \multirow[t]{2}{*}{ Location } & \multicolumn{3}{|c|}{$\begin{array}{c}\text { Number } \\
\text { of lizards (\%) }\end{array}$} & \multicolumn{3}{|c|}{$\begin{array}{l}\text { Typical arrangement } \\
\text { of scales (\%) }\end{array}$} & \multicolumn{3}{|c|}{$\begin{array}{c}\text { Non-typical arrangement } \\
\text { of scales }(\%)\end{array}$} \\
\hline & के & 우우 & juv. & $\hat{\partial} 0^{\pi}$ & 우우 & juv. & 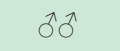 & 우우 & juv. \\
\hline Żary & 46 (27.1) & 53 (31.1) & 71 (41.8) & 37 (26.2) & 45 (31.9) & $59(41.9)$ & $9(31)$ & $8(27.6)$ & $12(41.4)$ \\
\hline Z. Góra & $45(30)$ & $48(32)$ & 57 (38) & $34(28.8)$ & 35 (29.7) & 49 (41.5) & $11(34.4)$ & $13(40.6)$ & $8(25)$ \\
\hline Nowa Sól & 93 (32.4) & 108 (37.6) & $86(30)$ & 70 (31.7) & 79 (35.7) & 72 (32.6) & $23(34.9)$ & $29(43.9)$ & $14(21.2)$ \\
\hline
\end{tabular}

The most common deviations from the pattern $1 / 2$ occurred in the lizards from Nowa Sól. Further, their biggest variations related to as many as 9 deviations $(1 / 0,1 / 1$ / Fig. $1 B /, 1 / 3,2 / 0,2 / 1,2 / 2,2 / 3,2 / 7$ /Fig. 1D/ and 3/2). $25 \%$ of changes in the arrangement of the scales were detected in males, $27 \%$ of changes were observed in females, and $16 \%$ in juvenile lizards. The $2 / 2$ arrangement was the most common (Fig. 1C). The lizards from Zielona Góra had the smallest variation of deviations as they occurred only in two patterns, namely 1/1,1/2 with equal frequency. The scale arrangements that have been described occurred in $25 \%$ of males, $27 \%$ of females and $14 \%$ of juveniles. In lizards from Żary, the changes related to four patterns of deviations, specifically, 
patterns $1 / 1,2 / 1,2 / 2$ and $3 / 2$. Pattern $2 / 2$ was the most common. Various scale arrangements were observed within the same population in $20 \%$ of males, $15 \%$ of females and $17 \%$ of juveniles. No differences in the occurrence of deviations among the populations $(x 2=10.83, d f=10, P=0.37)$ and between females and males $(x 2=9.97$, $d f=1, P=0.99)$, were observed, however considerable differences between adults and juveniles $\left(x^{2}=4.60, d f=1, P=0.032\right)$ were noticed.

$A$
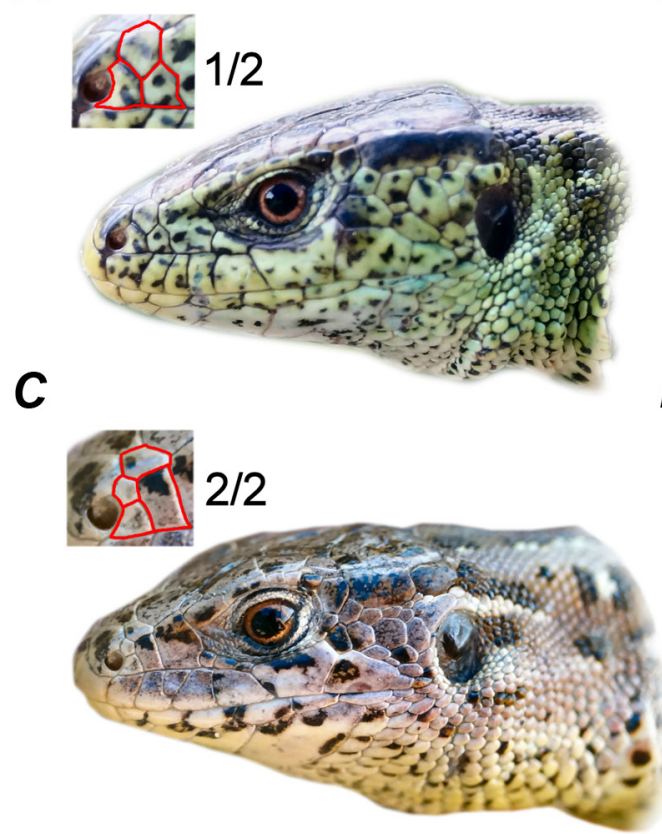

$\boldsymbol{B}$

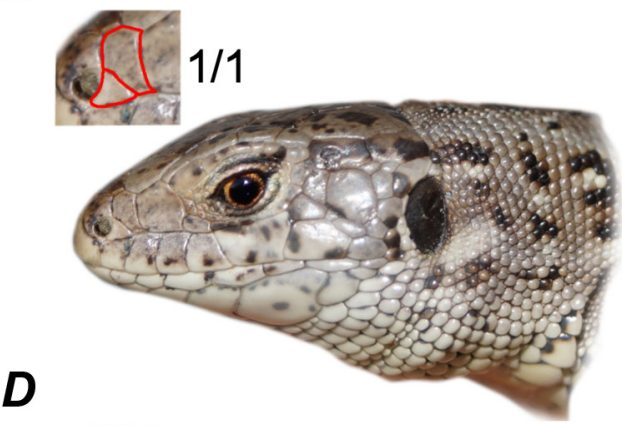

$2 / 7$

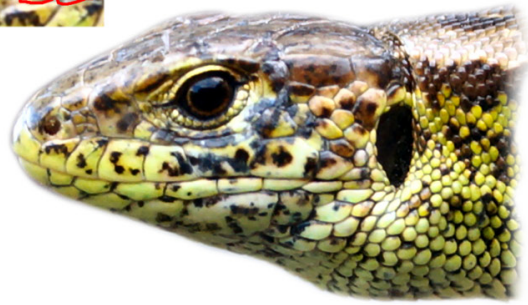

Fig. 1. Examples of the arrangements of scuta postnasalia and scuta frenale in the sand lizards within the studied populations. $\boldsymbol{A}$ - typical pattern (1/2); $\boldsymbol{B}-\boldsymbol{D}$ - non-typical patterns (1/1,2/2 and 2/7). $\boldsymbol{A}$ and $\boldsymbol{D}$ - males from Nowa Sól; $\boldsymbol{B}$ - female from Żary; $\boldsymbol{C}$ - female from Zielona Góra

\section{DISCUSSION}

Although the sand lizard is one of the most popular reptile species in Poland, the systematic membership of some of the populations may be quite challenging to establish. This is also the case with the population in Poland where you can expect to find specimens such as $L$. agilis agilis or L. agilis argus, and these are still difficult to differentiate based on the morphological features [12]. However, in the light of the relatively new molecular research conducted by $\mathrm{C}$. Andres et al. [1; 2], distinctive features of these two genetic characteristics were successfully established.

Numerous articles confirm the occurrence of changeability in the morphology of the head of sand lizards. W. Juszczyk [8] reported that out of 257 studied specimens, $66 \%$ demonstrated 7 deviations from the typical arrangement of postnasal scales and a loreal scale. The most common deviation was arrangement $1 / 1(19 \%)$ and the least common arrangement was 2/4 (2.6\% - 1 specimen). The research conducted by R. Kurczewski [10] showed deviations in $8 \%$ of individuals (7 males, 7 females, and 18 juv.). 
These deviations followed three patterns of deviations: $1 / 1,1 / 3$ and $2 / 2$. Moreover, the research by K. Dudek et al. [6] conducted on 124 specimens (62 females and 62 males) demonstrated a non-typical arrangement of postnasal scales in $32 \%$ of the specimens. The non-typical arrangement mainly included pattern $1 / 1$, with patterns $2 / 2,2 / 0,1 / 0,0 / 2$ occurring less frequently. The authors here observed no significant differences in deviations between both sexes.

Our research confirmed the observations of other authors that relate to a high changeability in the morphology of postnasal scales and a loreal scale in sand lizards. Compared to the above-cited studies, in the population of lizards from Nowa Sól, a high number of variations (9) in the patterns of deviations was observed as opposed to the populations from Zielona Góra and Żary, with 2 patterns and 4 patterns of deviations, respectively. In our research, we do not distinguish differences between sexes (that are of statistical importance). However, we do indicate that there are differences between adult lizards and juveniles. The deviations from a typical arrangement of postnasal scales and a loreal scale in sand lizards are subject to numerous discussions. Experimental research demonstrated that the frequency of these phenomena is influenced by internal factors (the genome) [14] and external factors [7]. However, the relationships between these factors are not clear. 9 patterns of deviations in the arrangement and the number of postnasal scales and a loreal scale in the population of lizards from Nowa Sól could be explained in terms of external factors such as a higher average temperature over a 24-hour period during the incubation period (in comparison with other populations) (own materials). L. Idrisowa [7] reports that newly-born sand lizards incubated in higher temperatures demonstrated the highest number of deviations and the highest frequency in the arrangement of the scales, their additional division, incomplete segregation, their mutual connections, lack of scales or their untypical arrangement, size and shape. The results of our research confirm the fact that the number and arrangement of the postnasal scales and one (or more than one) loreal scale are not reliable indicators that can be applied in order to establish the systematic membership of $L$. agilis.

This research was approved by the Regional Directorate for Environmental Protection (permit No. WPN-I.6401.206.2015.JK) and the Local Ethics Commission for Animal Experiments (Resolution No. 70/2016).

\section{COMPLIANCE WITH ETHICAL STANDARDS}

Conflict of Interest: The authors declare that the research was conducted in the absence of any commercial or financial relationships that could be construed as a potential conflict of interest.

Human Rights: This article does not contain any studies with human subjects performed by the any of the authors.

Animal studies: All institutional, national and institutional guidelines for the care and use of laboratory animals were followed.

1. Andres C., Franke F., Bleidorn C., Bernhard D., Schlegel M. Phylogenetic analysis of the Lacerta agilis subspecies complex. Systematics and Biodiversity, 2014; 12(1): 43-54.

Crossref • Google Scholar

2. Andres C., Franke F., Bleidorn C., Bernhard D., Schlegel M. Phylogenetische Analyse und genetische Differenzierung der Unterarten Lacerta agilis agilis und Lacerta agilis argus. Zeitschrift für Feldherpetologie, 2015; 22: 25-34. 
3. Berger L. Płazy i gady Polski. Klucz do oznaczania. PWN, Warszawa-Poznań, 2000; 146 s. Google Scholar

4. Bischoff W. Zur Verbreitung und Systematik der Zauneidechse, Lacerta agilis Linnaeus 1758.

Mertensiella, 1988; 1: 11-30.

Google Scholar

5. Blanke I. Die Zauneidechse. Zwischen Licht und Schatten. Beiheft der Zeitschrift für Feldherpetologie 7. Laurenti-Verlag, Bielefeld, 2010; 176 s.

6. Dudek K., Sajkowska Z., Gawałek M., Ekner-Grzyb A. Układ i liczba tarczek zanozdrzowych jako cecha taksonomiczna jaszczurki zwinki Lacerta agilis i jaszczurki żyworodnej Zootoca vivipara. Chrońmy Przyrodę Ojczystą, 2014; 70(1): 83-87.

Google Scholar

7. Idrisova L.A. The effect of incubation temperature on deviations of pholidosis and malformations in grass snake Natrix natrix (L. 1758) and sand lizard Lacerta agilis (L. 1758). The second international conference. Amphibian and reptiles anomalies and pathology: methodology, evolutionary significance, monitoring and environmental health. KnE Life Sciences, 2018; 70-74 pp.

Crossref $\bullet$ Google Scholar

8. Juszczyk W. Płazy i gady krajowe. Polskie Wydawnictwo Naukowe, Warszawa, 1987; $722 \mathrm{~s}$.

9. Kotenko T.I., Sviridenko Ye.Yu. Variability of coloration and pattern of the sand lizard, Lacerta agilis (Reptilia, Sauria, Lacertidae): methodic aspects. Vestnik Zoologii, 2010; 44(2): 137162. (In Russian)

Google Scholar

10. Kurczewski R. Jaszczurka zwinka (Lacerta agilis Linnaeus, 1758) w Wielkopolskim Parku Narodowym. Bogucki Wydawnictwo Naukowe Poznań, 2014; 85 s.

Google Scholar

11. Nekrasova O.D., Oskyrko O., Marushchak O. Color features of sand lizards, Lacerta agilis (Sauria, Lacertidae), in Kyiv Region (Ukraine). Vestnik Zoologii, 2018; 52(6): 495-500.

Crossref $\bullet$ Google Scholar

12. Sura P. Jaszczurka zwinka Lacerta agilis Linnaeus, 1758. In: Głowaciński Z., Sura P. (Ed.) Atlas płazów i gadów Polski. Status, rozmieszczenie, ochrona. Polskie Wydawnictwo Naukowe, Warszawa, 2018; 94-96.

Google Scholar

13. Tuniyev S.B., Tuniyev B.S. Interspecific variation of the sand lizard (Lacerta agilis) from the Western Caucasus and description of a new subspecies Lacerta agilis mzymtensis ssp. nov. (Reptilia: Sauria). Russian Journal of Herpetology, 2008; 15(1): 55-66. Google Scholar

14. Velo A.G., Becker C.G., Cordero-Rivera A. Turtle carapace anomalies: the roles of genetic diversity and environment. PLOS ONE, 2011; 6(4): 1-11.

Crossref $\bullet$ PubMed $\bullet$ Google Scholar

15. www.reptile-database.org

Received / Одержано 10 August 2020
Accepted / Прийнято

31 August 2020
Published / Опубліковано

30 September 2020

ISSN 1996-4536 (print) • ISSN 2311-0783 (on-line) • Біологічні Студії / Studia Biologica • 2020 • Том 14/№3 • С. 105-110 